\title{
The Relationship between Individual Factor and Risk of Low Back Pain on Broomstick Makers in Silau Padang Village, Serdang Bedagai Regency
}

\author{
Muhraza Siddiq, Gerry Silaban, Nurmaini \\ Faculty of Public Health, Universitas Sumatera Utara, Medan, Indonesia \\ Email:muhraza.siddiq@gmail.com
}

\begin{abstract}
:
Low Back Pain (LBP) is pain in the lower back originating from the spinal area (lower back), muscles, nerves, tendons, joints and cartilage. Individual risk factor for LBP include years of service, age, gender, work attitude and smoking habits. This study aims to determine the relationship between individual factor and risk of Low Back Pain of broomstick makers in Silau Padang village, Serdang Bedagai Regency. This type of research was an observational study with cross-sectional design. The population in this study was amounted to 30 people with sampling techniques using a total sampling of 30 people. The analysis used was Chi-Square with a significance level $a=0.05$, the data collection method used was a questionnaire. This study found individual factor associated with LBP risk were age ( $p$ score $=0.009, p$ score $<0.05)$ and work attitude ( $p$ score $=0.01, p$ score $<0.05)$. While the length of work ( $p$ score $=0.07)$, gender ( $p$ score $=$ $0.1)$ and smoking habits $(p$ score $=0.07)$ are not related to LBP risk $(p$ score $>0.05)$. Only work attitudes were associated with LBP risk, so interventions were needed in the form of counseling to improve the work attitude of broomstick makers in Silau Padang Village, Serdang Bedagai Regency.

Keywords:

individual factor; risk of low back pain
\end{abstract}

\section{Introduction}

Informal workers in urban or rural areas have almost the same problems namely security and health problems. Informal sector workers generally do not have a safe work environment and lack welfare facilities. According to global data about 2 million people die each year related to their work (ILO, 2013). BPJS Employment recorded the number of work accidents in 2017 reported as many as 123,041 cases, while in 2018 there was an increase of 173,105 cases (BPJS, 2018).

Based on estimates of the International Labor Organization (ILO), 2.78 million workers die every year. Around $86.3 \%$ (2.4 million workers) of them died due to occupational diseases (PAK), while around 13.7\% (380,000 workers) died from work-related accidents (ILO, 2018). Research from the Bureau of Labor Statistics (BLS) in 2013 that mentioned cases of MSDS (musculoskeletal disorders) accounted for 33\% of all cases of injury and disease (OSHA, 2017).

Low Back Pain (LBP) is pain in the lower back from the spinal region (lower back), muscles, nerves, tendons, joints and cartilage (Suma'mur, 2009). According to Andini's (2015) research on "Risk Factors of Low Back Pain in Workers" states the risk factors for LBP occurrence in workers consist of personal factors, work factors and environmental factors. Personal factors are work time, work period, smoking, education status, income, activity and trauma. Work factors consist of workload, work position, repetition and duration while environmental factors consist of noise and vibration throughout the body. 
Sulaeman's research (2015) states that there is no relationship between sex, work experience, body mass index (BMI), smoking behavior and exercise habits with LBP events. Factors affecting LBP events are age, years of service and level of back exposure.

According to Mentari et al (2020) in Public Works Department of Medan when the study of people with impaired lung function restrictive have such complaints often feel short of breath when working, often have a persistent cough and often feel chest pain. This is in line with Khumaidah (2009), exposure to long and frequent respiratory complaints can cause high against the risks of obstructive lung disease.

According to Riningrum (2016) in his research stating that the cause of LBP is influenced by attitudes and years of service. This is because the attitude of sitting with a bent position and bowing too long in the long term can cause the muscles to become me and will damage soft tissue. The wrong body position always sits, creating abnormal pressure from the tissues, causing pain. The pressure of the disc is greater in the sitting position upright than in the standing position and becomes even greater in the sitting position with the body bending forward.

Research conducted by Samara (2005) states that workers who sit static 91-300 minutes have proven to be a risk factor for LBP. This results in the longer a person sits because of muscle tension and ligament tension, especially the longitudinal is posior longitudinal ligament increases, especially with slouching.

The broomstick makers is one of the informal jobs where every stage of the process starts from collecting raw materials namely oil palm leaves taken from the PTPN 3 Gunung Pamela plantation area or from oil palm plantations owned by the community itself, then the process of transportation from the garden to the house using a bicycle motorcycle. Furthermore, the focus of this research is at the stage of the process of cleaning the leaf bones (sticks) of palm oil leaves which the process is done by sitting with a chair or sitting on the floor without using a table as a tool, usually the workers do this cleaning at home or in plantation so that in this process there can be a risk of LBP occurring to workers, then the drying process to the sale.

According to a preliminary survey of broomstick makers in the village of Silau Padang, the risk of Low Back Pain (LBP) is very large due to the age of the workers who are on average 30 years old and work with attitudes such as bending or sitting for a long time that is 3-4 hours and working time which has exceeded 2 years. Of the 12 workers observed there were 7 people who were at risk of experiencing LBP.

Based on the above explanation the researchers are interested in knowing the relationship between individual factor and risk of Low Back Pain on broomstick makers in Silau Padang Village, Serdang Bedagai Regency.

\section{Research Methods}

This type of research was an observational cross sectional design that aims to determine the relationship between individual factor and LBP risk on stick makers in Silau Padang Village, Serdang Bedagai Regency. The population in this study were all broomstick makers of 30 people. The research sample consisted of 30 people with total sampling techniques. The independent variable was an individual factor (years of service, age, gender, work attitude and smoking habits) and the dependent variable was the risk of low back pain. Data collection method was a questionnaire with a statistical test using the Chi-Square test. 


\section{Discussion}

\subsection{Result}

Distribution table 1. Frequency factors of individual broomstick makers in Silau Padang Village, Serdang Bedagai Regency.

Table 1. Frequency Distribution of Individual Factors of Broomstick Makers

\begin{tabular}{llll}
\hline Variable & & $\mathbf{N}$ & $\mathbf{0}$ \\
\hline Years of Service & 2 & 8 & 26,7 \\
\hline & 3 & 14 & 46,7 \\
\hline Age & 4 & 8 & 26,7 \\
\hline & $24-46$ & 5 & 16,7 \\
\hline & $47-55$ & 6 & 20,0 \\
\hline Gender & $56-59$ & 10 & 33,3 \\
\hline & $60-64$ & 9 & 30,0 \\
\hline Work Attitude & Male & 9 & 30 \\
\hline & Female & 21 & 70 \\
\hline & Standard & 5 & 16,7 \\
\hline Smoking & Medium & 6 & 20 \\
\hline & High & 19 & 63,3 \\
\hline & Yes & 8 & 26,7 \\
\hline
\end{tabular}

From the above table, it can be seen that as many as 14 workers (46.7\%) have worked for 3 years, the age of broomsticks maker 56 to 59 years as many as 10 people with female that is 21 people $(70 \%)$ with risky work attitudes very high as many as 19 people and 22 people $(73.3 \%)$ smokers. Table 2. Distribution of individual factors related to LBP risk of broomstick-makers in Silau Padang Village, Serdang Bedagai Regency.

Table 2. Distribution of Individual Factors related to LBP Risk

\begin{tabular}{|c|c|c|c|c|c|c|c|c|c|c|}
\hline \multirow{3}{*}{\multicolumn{2}{|c|}{ Individual Factors }} & \multicolumn{8}{|c|}{ The Risk of LBP } & \multirow{3}{*}{$\begin{array}{l}\text { Score } \\
\mathbf{P}\end{array}$} \\
\hline & & \multicolumn{2}{|c|}{ Low } & \multicolumn{2}{|c|}{ Standard } & \multicolumn{2}{|c|}{ Medium } & \multicolumn{2}{|c|}{ High } & \\
\hline & & $\mathbf{n}$ & $\%$ & $\mathbf{n}$ & $\%$ & $\mathbf{n}$ & $\%$ & $\mathbf{N}$ & $\%$ & \\
\hline \multirow{3}{*}{$\begin{array}{l}\text { Years of } \\
\text { Service }\end{array}$} & 2 & 0 & 0 & 2 & 25.0 & 0 & 0 & 6 & 75,0 & \multirow{3}{*}{0072} \\
\hline & 3 & 0 & 0 & 0 & 0 & 1 & 7,1 & 13 & 92,9 & \\
\hline & 4 & 1 & 12,5 & 0 & 0 & 2 & 25.0 & 5 & 62,5 & \\
\hline \multirow[t]{4}{*}{ Age } & $24-46$ & 1 & 15 & 1 & 15 & 1 & 15 & 2 & 55 & \multirow{4}{*}{0009} \\
\hline & $47-55$ & 0 & 0 & 0 & 0 & 0 & 0 & 5 & 100 & \\
\hline & $56-59$ & 0 & 0 & 1 & 15 & 2 & 12 & 7 & 73 & \\
\hline & $60-64$ & 0 & 0 & 0 & 0 & 0 & 0 & 9 & 100 & \\
\hline \multirow[t]{2}{*}{ Gender } & Male & 1 & 11,1 & 1 & 11,1 & 2 & 22,2 & 5 & 55,6 & \multirow{2}{*}{0133} \\
\hline & Female & 0 & 0 & 1 & 4,8 & 1 & 4,8 & 19 & 90,5 & \\
\hline \multirow{3}{*}{$\begin{array}{l}\text { Work } \\
\text { Attitude }\end{array}$} & Standard & 1 & 20 & 2 & 40 & 1 & 20 & 1 & 20 & \multirow{3}{*}{0001} \\
\hline & Medium & 0 & 0 & 0 & 0 & 2 & 33,3 & 4 & 66,7 & \\
\hline & High & 0 & 0 & 0 & 0 & 0 & 0 & 19 & 100 & \\
\hline \multirow{2}{*}{ Smoking } & Yes & 1 & 12,5 & 1 & 12,5 & 2 & 25.0 & 4 & 50,0 & \multirow{2}{*}{0072} \\
\hline & No & 0 & 0 & 1 & 4,5 & 1 & 4,5 & 20 & 90,9 & \\
\hline
\end{tabular}


The results of bivariate analysis using the Chi-Square test obtained p score $=0.009$ for the age variable and $p=0.001$ for the work attitude variable which means that there is a relationship between age and work attitude with LBP risk marked by ap score $<0.05$.

\subsection{Discussion}

The results of the bivariate analysis of all independent variables on the dependent variable indicate that only age and work attitude are associated with the risk of Low Back Pain in broomstick makers in Silau Padang Village, Serdang Bedagai Regency. Based on the observations, it was found that workers have an average age of 30 years and over and work attitudes that are not in accordance with ergonomic theory. This is consistent with research conducted by Sulaeman (2015) which states there is no relationship between work experience, Body Mass Index (BMI), smoking behavior and exercise habits with the incidence of Low Back Pain. Factors that influence the incidence of low back pain are age, years of service and the level of reexposure.

And reinforced by research Riningrum (2016) states that the cause of LBP is influenced by attitudes and years of service. This is because sitting in a bent and bent position for a long time can cause muscle stiffness and will damage the soft tissue. Incorrect body position when sitting makes abnormal pressure on the tissue, causing pain. Disc pressure is greater in an upright sitting position compared to a standing position and becomes greater when sitting by bending forward.

\section{Conclusion}

The age of the broomstick makers poses a risk of back pain because as a person gets older, the endurance of the muscles, bones and support systems of the body will decrease in function so that it can become rigid, narrow and painful as well as non-ergonomic and bad work attitudes which are at high risk for LBP because workers when doing work they do not pay attention to attitude or position when working. Whether it's sitting on the floor or using a small bench without a backrest.

\section{References}

Alodokter. (2015). Nyeri Punggung, Gejala, Penyebab Dan Mengobati. (Http://www.alodokter.com, diakses 20 maret 2017).

Andini, F. (2015). Risiko Pabrik Low Back Pain di Pekerja. J Mayoritas. Vol. 4 No 1. Januari 2015.

Butterworth. (1974). Terapan Ergonomi Handbook. London

BPJS Ketenagakerjaan. (2018). Berita \& Peristiwa: Menaker Hanif Dorong Pemda Bikin Komitmen Keselamatan dan Kesehatan Kerja (K3) di Wilayahnya. Diakses Tanggal 14 September 2018. (https://www.bpjsketenagakerjaan.go.id/berita/23322).

RS Bridger (2018). Pengantar Faktor Manusia dan Ergonomics4th Ed. Tailor \& Francis Group. London.

Bridger, RS (2008). Pengantar Ergonomi International Edition. Singapura: McGrawHill Book Co RS Bridger (2003). Pengantar Ergonomi, 2nd Ed. Tailor \& Francis Group. London.

Buntarto. (2015). PANDUAN Praktis Keselamatan dan Kesehatan Kerja untuk review Industri. Yogyakarta: Pustaka Baru Press.

Dachlan, LM (2009). Pengaruh Kembali Latihan PADA Nyeri Punggung Bawah. Tesis Magister Kedokteran Keluarga Universitas Sebelas Maret. Surakarta. (https://eprints.uns.ac.id/2353/) 
Grandjean, E. (1993). Pas Tugas ke Man, 4th ed. Taylor \& Francis Inc London.

Graveling, R. (2019). Ergonomi dan Gangguan Musculoskeletal (MSDS) di Tempat Kerja A Forensik dan Analisis epidemiologi.Tailor \& Francis Group, London.

Humantech, Inch. (1995). Humantech Terapan Ergonomis Pelatihan Manual. Disiapkan untuk Procter \& Gamble Inc., 2nd Ed. Barkeley Vale. Australia.

ILO, (2013). Keselamatan dan Kesehatan Kerja, Sarana untuk review Produktivitas: Pedoman Pelatihan untuk review Maneger Dan Pekerja: Jakarta.

Johns, R. (1994). Kronis berulang Back Pain. Jom 36 (5): 537-547.

Kemenkes RI, (2014). Pedoman Pos Upaya Kesehatan Kerja Terintegrasi (Bagi Petugas Kesehatan): Direktorat Bina Kesehatan Kerja dan Olahraga, Jakarta.

Ningsih, LN (2009). Asuhan Keperawatan PADA Klien DENGAN Gangguan Sistem Muskuloskeletal. Jakarta: Salemba Medika

NIOSH. (1997). Gangguan Musculoskletal dan Tempat Kerja Faktor: Sebuah Tinjauan Kritis dari Epidemiologi Bukti untuk Gangguan Kerja Terkait Musculoskletal. NIOSH: Pusat Pengendalian dan Pencegahan Penyakit.

Notoatmodjo, SA (2010). Metodologi Penelitian Kesehatan. Jakarta: PT. Rineka Cipta.

OSHA. (2017). Pencegahan Musculoskletal Disorder di Tempat Kerja. Diakses 16 Maret 2018. (https://www.osha.gov/SLTC/ergonomics).

Parjoto. (2006). Terapi Listrik untuk review Modulasi Nyeri.Ikatan Fisioterapi Indonesia: Semarang.

Pheasant, S. (1991). Ergonomi, Kerja dan Kesehatan. Aspen Penerbit, Inc USA.

Pulat, BM (1992). Dasar-dasar Ergonomi Industri. Jersey baru. Prentice Hall, Inc.

Purwanto, S. (2008). Sikap Kerja Perawat. Diakses Tanggal 22 Januari 2019. (www.Artikel_Psikologis_Klinis_dan_Perkembangan.htm.id).

Rahayu, EP (2015). Hubungan Antara Pengetahuan, Sikap, Dan Perilaku Karyawan DENGAN Penerapan Manajemen Budaya Keselamatan dan Kesehatan Kerja. Diakses Tanggal 4 Juni 2016. (http:/ / ejournal.htp.ac.id/stikes/pdf.php?id=JRL0000107)

Riningrum, H. (2016). Pengaruh Sikap Kerja, Usia Dan Masa Kerja Terhadap Keluhan Low Back Pain. Jurnal Pena Medika Vol.6 No.2 Desember 2016.

Roupa, et al. (2008), Masalah Dari Lower Back Pain Dalam Keperawatan Staf Dan Its Effect Pada Kegiatan Manusia, Ilmu Kesehatan Journal, Volume 2 No 4 tahun 2008.

Samara, D. (2005). Duduk Statis Sebagai Faktor Risiko Terjadinya Nyeri Punggung Bawah PADA Pekerja Perempuan. Jurnal Universa Medicina. Vol. 24. 2005. (https://univmed.org/wpcontent/uploads/2011/02/Diana(1).pdf)

Shidarta, P. (1999). Neurologi klinis Dalam Praktek Umum. Jakarta: Dian Rakyat.

Stack, T. Lee T, Ostrom dan Cheryl A, Wilhelmsen. (2016).Kerja Ergonomi.John Wiley \& Sons. Kanada.

Sucipto, CD (2014). Keselamatan dan Kesehatan Kerja. Gosyen Penerbitan: Cetakan I. Yogyakarta.

Sulaeman, Y. (2015). Low Back Pain PADA Pekerja di Divisi Minuman Tradisional (Studi KASUS CV. Cihanjuang Inti Teknik). Jurnal Teknik Lingkungan Vol. 21 No 2 Oktober 2015.

Suma'mur, PK (2009). Hiegiene Perusahaan Dan Keselamatan Kerja. Jakarta: CV Sagung Seto.

Suma'mur, PK (2013). Higiene Perusahaan dan Kesehatan Kerja.Jakarta: Sagung Seto.

Taha, H. (2006). Operasi pencarian. Jakarta: Binarupa Aksara.

Tarwaka. (2015). Ergonomi Industri, Dasar-Dasar Pengetahuan Ergonomi Dan Aplikasi di Tempat Kerja. Surakarta: Harapan Press.

Tarwaka. (2013). Ergonomi Industri. Surakarta: Harapan Press.

Tarwaka. (2011). Ergonomi Industri, Dasar-Dasar Pengetahuan Ergonomi Dan Aplikasi di Tempat Kerja. Surakarta: Harapan Press. 
Tarwaka. (2010). Ergonomi Industri. Surakarta: Harapan Press.

Taylor, G. Kellie Paskah dan Roy Hegner. (2004). Meningkatkan Keselamatan dan Health.Elsevier Butterworth-Heinemann. Oxford.

Triwibowo, C. (2013). Kesehatan Lingkungan Dan K3. Nuha Medika: Cetakan Pertama: ISBN: 978-602-1547-16-8: Yogyakarta.

Umami, AR (2014). Hubungan ANTARA karakteristik responden Dan SIKAP kerja Duduk DENGAN Keluhan Nyeri Punggung Bawah (rendah sakit punggung) PADA pekerja $\begin{array}{lllll}\text { batik tulis. Diakses Tanggal } 5015 & \end{array}$ (http://jurnal.unej.ac.id/index.php/JPK/article).

Mentari, D.S., Ashar, T., Nurmaini. (2020). The Relationship between Work Period and Dust Level with Disruption of Lung Capacity in Asphalt Mixing Plant Production Workers (AMP) Medan in Public Works Office 2019. Britain International of Humanities and Social Sciences Journal, 115-119.

Minggu, L. James, Barry S. Levy dan Gregory R. Wagner. (1991). Mencegah penyakit dan kecelakaan kerja. Washington DC: American Association kesehatan masyarakat.

Wulandari, D. (2011). Pengaruh Perbaikan Kursi Kerja Terhadap Keluhan Muskuloskeletal PADA Pekerjaan Menjahit di Desa Sawahan Kecamatan Juwiring Kabupaten Klaten. Surakarta: Fakultas Kedokteran Universitas Sebelas Maret. (https:/ / eprints.uns.ac.id/6045/1/197181711201109131.pdf).

Yassierli, I. (2014). Ergonomi Suatu Pengantar. Rosda Jaya Putra. Bandung. 